\title{
Fenomen „rogu obfitości” w faktograficznej rekonstrukcji programu intelektualnego Alvina Warda Gouldnera
}

DOI: 10.19195/2083-7763.9.6

\section{Wprowadzenie}

Bezkresność świata człowiek próbuje okiełznać poprzez zobiektywizowaną naukową jego obserwację. Zmagania te określić można mianem naukotwórczej działalności o refleksyjnym charakterze, przyczyniającej się do formułowania coraz to ciekawszych wizji obserwowanych zjawisk, fenomenów czy mechanizmów. Poznawcza działalność człowieka o twórczym charakterze nie tylko odsłania nam prawdy o świecie, lecz także nadaje im odpowiednie postaci. Propozycje wielu stanowisk teoretycznych wyrażone są określonymi sformułowaniami. Jedne ustalenia tworzą zupełnie odrębną grupę faktów, odmiennych w swej istocie od istniejących. Drugie przyczyniają się do rozwoju dotychczasowych osiągnięć ze względu na dostrzeżenie przez badaczy możliwości ich zmiany, a tym samym dokonania postępu. Z kolei pomiędzy innym stanowiskami zauważalna jest jakaś współmierność, połączona $\mathrm{z}$ niezwykłą skrupulatnością, odnotowująca odchylenia czy różnice. Wielość istniejących stanowisk jest wynikiem wysiłku zmierzającego do adekwatnego opisu rzeczywistości. Pomiędzy wieloma utrwalonymi stanowiskami artykułowane są uzasadnienia statusu obserwowalnych - niekoniecznie zawsze wprost - fragmentów owej rzeczywistości społecznej. Ponoszone przez naukowców wysiłki uprawomocniają daną dyscyplinę nauki poprzez formułowane twierdzenia, postulaty czy też uzasadnienia kontekstu danego odkrycia. Wiele z tych znaczących dokonań jest dla nas niezwykłą inspiracją, ale również swoistym dowodem geniuszu intelektualnego skupiającego naukowców wokół określonego rodzaju intelektualnego establishmentu. 
Odwołując się do swoich racji, naukowcy i badacze żywo debatują na temat nauki jako praktyki społecznej, przyjmując określoną ideologię formującą jej status. Wszelkie rozważania w tym zakresie przyczyniają się jednak do usytuowania różnych konfiguracji stanowisk w określonych miejscach dialektycznych sieci poznawczych. Odnosi się nieodparte wrażenie niemożności przezwyciężenia braku konsensusu występującej ich wielości. Dokonując jednak systematycznego przeglądu, z każdej z nich czerpać możemy bogactwo na rzecz pełniejszego zrozumienia rzeczywistości społecznej. Istotne jest jednak zachowanie ostrożności w niefrasobliwym przenoszeniu kategorii danej teorii do kontekstu zupełnie sprzecznego $\mathrm{z}$ intencjami autora ${ }^{1}$.

W naukach społecznych wyjątkowo zmagamy się z wieloznacznością pojęć i niemożnością wypracowania jednoznacznego stanowiska w niemalże każdej przedmiotowej kwestii. Pomimo tych istotnych różnic przybliżenie owych koncepcji oraz kontekstu ich tworzenia może nam odsłaniać kwestie dotychczas nieuświadomione, przez co każda z tych perspektyw może służyć odkrywaniu tego, co zakryte. Działalność naukowa, mimo iż realizowana już tak długo, ma jeszcze wiele do odkrycia i zweryfikowania. Różne perspektywy oglądu tych samych kwestii mogą służyć realizowaniu ustawicznej refleksji. Zmagania naukowe nie są również działalnością łatwą, wiążą się z niezwykłym trudem, niepewnością, ale mogą przynieść wiele satysfakcji dla naukowców podejmujących próbę odgadnięcia istoty czy opisania architektury owego świata w kontekście danej dyscypliny naukowej.

Niezwykle często mamy do czynienia z rozproszeniem wysiłków zmierzających do konceptualizacji konkretnego zagadnienia będącego przedmiotem naukowej oraz badawczej działalności. Wielość definicji rozważanych zagadnień niemalże równa się liczbie zaangażowanych w ten proces teoretyków i badaczy. Jedne są szersze, inne węższe, jedne są sformułowane wyraźniej, inne z określonej perspektywy, jeszcze inne są poszerzane w stosunku do swojego pierwowzoru. Poziom skomplikowania wzrasta niewspółmiernie, gdy zaczniemy roztrząsać ich szczegóły interpretacyjne, chociaż status ten równoważyć może określona tradycja intelektualna, z której wyrastają te rozważania. Możliwe, że przyczyn tego stanu rzeczy należy upatrywać w „obrazach mentalnych" ${ }^{2}$ oraz w sposobie przekazu subiektywnych koncepcji rozważanych problematów przez uczonych. O ile zabiegi konceptualizacji, operacjonalizacji czy pomiaru są istotne, o tyle są niewystarczające dla pełnego zrozumienia otaczającej rzeczywistości. Kategoryzacja danego zagadnienia staje się swoistym elementem poszukiwania głębszych prawd o świecie.

W kontekście socjologii debaty na temat bezkresności świata oraz fenomenu jego opisu także nie milkną. Recepcje określonych reżimów myślenia dostarcza-

${ }^{1}$ M. Horkheimer, Zmierzch. Notatki z Niemiec 1931-1934, przeł. H. Walentowicz, Warszawa 2002, s. 30.

${ }^{2}$ E. Babbie, Podstawy badań społecznych, przeł. W. Betkiewicz et al., Warszawa 2009, s. 144. 
ją nam ram do interpretacji obserwowalnych zjawisk społecznych. Przedmiotem moich poczynań badawczych jest rekonstrukcja programu intelektualnego wyrażonego w najważniejszych dziełach Alvina Warda Gouldnera. Jest on tak interesującą postacią intelektualnego establishmentu, że wiele jego dzieł może być uznanych za magnum opus socjologii. „Mapa” relacyjnych tematów, wątków oraz zagadnień współtworzy jego niezwykle szczegółowe i wielowymiarowe osiągnięcia. Bez wątpienia wyjątkowe poczucie świadomości intelektualnej Gouldnera rozbrzmiewa po dziś dzień w jego pracach i inspiruje badaczy społecznych. Można tylko ubolewać nad niedostatecznym upowszechnianiem niektórych dokonań Gouldnera w naszej rodzimej socjologii. Doceniając wartość poczynionych wysiłków teoretyczno-empirycznych, autorka niniejszego opracowania stara się, chociaż w minimalnym zakresie, wypełnić tę lukę, prezentując dokonania Gouldnera nieprzetłumaczone jeszcze na język polski.

\section{Program intelektualny Alvina Warda Gouldnera}

Alvina W. Gouldnera uznaje się za jednego z bardziej wpływowych, a zarazem płodnych intelektualnie socjologów okresu powojennego w Stanach Zjednoczonych. Jego wzrost w establishmencie naukowym - chociaż sam nie lubił tego określenia - został w bardzo interesujący sposób przedstawiony przez Andrzeja Niesporka (odsyłam czytelników do tych interesujących ustaleń) ${ }^{3}$. Gouldner, pełniąc funkcję naukowca, bez wątpienia wpisał się w krąg osobistości określanych mianem the Founding Fathers szkoły chicagowskiej, współtworząc jedną $\mathrm{z}$ faz rozwojowych socjologii amerykańskiej ${ }^{4}$ wraz z wieloma wybitnymi teoretykami i badaczami społecznymi. Jego dorobek lokuje się w następujących obszarach: teorii funkcjonalistycznej ${ }^{5}$, marksizmu ${ }^{6}$ oraz teorii krytycznej ${ }^{7}$; w wyniku postępującej specjalizacji w dyscyplinie socjologii angażował się w rozwój socjologii

${ }^{3}$ A. Niesporek, Alvin Gouldner - teoretyk czy socjologiczny banita?, [w:] A.W. Gouldner, Kryzys socjologii zachodniej, przeł. P. Tomanek, Kraków 2010, s. 7-35.

${ }^{4}$ K. Czekaj, Socjologia Szkoły Chicagowskiej i jej recepcja w Polsce, Katowice 2007, s. 57.

${ }^{5}$ Ważniejsze opracowania: A.W. Gouldner, Some observations on systematic theory, [w:] Sociology in the United States of America, red. H. Zetterberg, Paris 1956; idem, Organizational analysis, [w:] Sociology Today: Problems and Prospects, red. R.K. Merton, L. Broom, L.S. Cottrell, Jr., New York 1959; idem, Reciprocity and autonomy in functional theory, [w:] Symposium on Sociological Theory, red. L. Gross, Evanston 1959; idem, The norm of reciprocity: preliminary statement, „American Sociological Reviev" 25, 1960, s. 161-178; A.W. Gouldner, R.A. Peterson, Notes on Technology and the Moral Order, Indianapolis IN 1962; A.W. Gouldner, For Sociology: Renewal and Critique in Sociology Today, New York 1973; idem, Against Fragmentation: The Origins of Marxism and the Sociology of Intellectuals, New York 1985.

${ }^{6}$ A.W. Gouldner, The Two Marxisms, New York 1980.

7 A.W. Gouldner, For Sociology: Renewal and Critique in Sociology Today, New York 1973; idem, The Coming Crisis of Western Sociology, New York 1970. 
organizacji i przemysłu ${ }^{8}$, socjologii wiedzy ${ }^{9}$, zajmował się rolą intelektualistów we współczesnym społeczeństwie ${ }^{10}$, zagadnieniami rewolucji komunikacyjnej ${ }^{11}$ czy wzajemnym oddziaływaniem nauki i ideologii ${ }^{12}$. Na język polski przetłumaczone zostały nieliczne jego prace, w tym monografia Kryzys socjologii zachodniej ${ }^{13}$ czy artykuły Norma wzajemności. Preliminaria ${ }^{14}$ i Anty-Minotaur, czyli mit socjologii wolnej od wartości $i^{15}$. Spektrum poruszanych przez tego socjologa zagadnień jest zdumiewające, wynika ono z jego wszechstronnych zainteresowań kształtowanych w toku naukowego rozwoju w amerykańskich ośrodkach akademickich.

Walter R. Nord w artykule Alvin W. Gouldner as Intellectual Hero zwraca uwagę na pięć niemalże heroicznych oraz przenikających się wymiarów określających samo-refleksyjną (self-reflexive) twórczość Gouldnera. Pierwszy wymiar propagowanego programu intelektualnego odnosi się do patologicznych konsekwencji pominięć w toku studiów teoretycznych. „First, Gouldner consistently called attention to what was not taken as problematic in a theory - theories' lacunae and their pathological consequences" "16. Dokonując krytycznej oceny Parsonsa w The Coming Crisis of Western Sociology czy podejmując się krytyki Marksa w The Two Marxisms, angażował się w poszukiwanie tego, co nie zostało uwzględnione w rozważaniach ich twórców, a co jednocześnie załamuje eksplikacyjną ich użyteczność. Taka postawa wiązała się z zaangażowaniem prowadzącym do pełnego zrozumienia zalet i wad danej idei. „Taka wartościująco-krytyczna dyspozycja umysłu zasługuje na najwyższe uznanie i stanowi maksymalnie wartościowy element myślenia twórczego" ${ }^{17}$. Wszelkie błędne, opaczne czy karykaturalnie ujęte idee nie przyczyniają się do postępu naukowego, natomiast odszukiwanie istotnych pominięć czy obciążeń w ich

${ }^{8}$ Ważniejsze opracowania: A.W. Gouldner, Studies in Leadership, New York 1950; idem, Patterns of Industrial Bureaucracy, Glencoe 1954.

9 A.W. Gouldner, The Dialectic of Ideology and Technology. The Origins, Grammar, and Future of Ideology, New York 1976.

${ }^{10}$ Ważniejsze opracowania: A.W. Gouldner, The Future of Intellectuals and the Rise of the New Class, New York 1979; idem, The dark side of the dialectic: Toward a new objectivity, „Sociological Inquiry" 46, 1976, s. 3-15; idem, The Dark Side of the Dialectic: The Future of Intellectuals and the Rise of the New Clas, Oxford 1982.

11 A.W. Gouldner, News and social science as ideology, „Quarterly Journal of Ideology” 2, 1978, s. $4-17$.

12 Ważniejsze opracowania: A.W. Gouldner, Anti-Minotaur: The myth of a value-free sociology, „Social Problems”, 9, 1962, s. 199-213; idem, The Dialectic of Ideology...

13 A.W. Gouldner, Kryzys socjologii zachodniej, przeł. P. Tomanek, Kraków 2010.

14 A.W. Gouldner, Norma wzajemności. Preliminaria, [w:] Współczesne teorie wymiany społecznej. Zbiór tekstów, red. M.M. Kempny, J. Szmatka, Warszawa 1992, s. 73-106.

15 A.W. Gouldner, Anty-Minotaur, czyli mit socjologii wolnej od wartości, [w:] Kryzys i schizma, t. 1, red. E. Mokrzycki, Warszawa 1984, s. 13-43.

16 W.R. Nord, Alvin W. Gouldner as Intellectual Hero, „Journal of Management Inquiry” 1, 1992, s. 351.

17 Z. Cackowski, Człowiek jako podmiot działania praktycznego i poznawczego, Warszawa 1979, s. $472-473$. 
treści - wręcz przeciwnie. Usiłowania te wymagają jednak niezwykłej erudycji oraz przeświadczenia o istotności znalezionej i niewyjaśnionej „luki” czy „obciążeñ” wyrażonych adekwatnymi kategoriami.

Dokonując recepcji dzieł Gouldnera, można zauważyć częstszą „krytykę” Maxa Webera ze względu na to, że krytyka ta była nie tylko uznawana za bezpieczniejszą, lecz także wpisywała się w kształtowanie dorobku z socjologii organizacji i przemysłu. Niezwykle inspirujące są rozważania Gouldnera przyrównującego weberowski postulat odróżnienia „sądów o wartościach od sądów o faktach” do labiryntu, w którym znajdował się mitologiczny Minotaur. Ten mitologiczny labirynt $\mathrm{w}$ swej istocie jest nierozpoznanym układem, $\mathrm{z}$ którego wnętrza prowadzi jedna, ale niełatwa do znalezienia droga. W mitologii labirynt ten symbolizuje skomplikowany problem, do którego rozwiązania prowadzić będzie jakieś twórcze rozwiązanie. W takiej właśnie pułapce tkwili socjologowie od początków kształtowania się nauki. Pułapką tą był weberowski mit „socjologii wolnej od wartościowania”, a tym samym legitymizowanie swoistej ideologii grupy zawodowej socjologów. Korzystnym rozwiązaniem w jego opinii było przełamanie weberowskiego imperatywu, ujawniając jego nieadekwatność. Dokonał on reorientacji tegoż postulatu obiektywizmu oraz obiektywności, dowodząc, że naukowiec jest moralnie i celowo-racjonalnie zaangażowany w tworzenie konkretnych form wiedzy. Imperatyw ten przez znaczny czas stanowił fragment ideologii grupy zawodowej socjologów, ograniczając ich zaangażowanie w tworzenie nauki.

Postulowane niejednokrotnie twierdzenia nie oznaczają krytyki przez duże K. Gouldner doceniał spuściznę dziedzictwa intelektualnego poprzedników. Krytyka jest tutaj rozumiana jako refleksyjna, a więc jako samoświadome dociekania zorientowane na poszukiwanie przekroczeń, ujawniających się z biegiem czasu słabości teoretycznych, nieuzasadnionych zniekształceń interpretacyjnych, redukcji niedopowiedzeń i słabości, przezwyciężania rutyny czy w końcu ukazywania nowych perspektyw teoretycznych ich rozwikłań. Refleksyjność lokuje się we wrażliwości badacza, a tą z kolei legitymizuje wiedza. Była to jego forma uprawiania refleksyjnej socjologii, socjologii, która miała aspiracje nadążyć za dokonującymi się przekształceniami realnego świata.

Drugi wymiar intelektualnego programu odnosi się do zerwania z praktykowaniem „dualizmu metodologicznego" polegającego na przeprowadzeniu wyraźnej linii demarkacyjnej między przedmiotem a podmiotem ${ }^{18}$. Rozróżnianie odrębnych postaci podmiotów i przedmiotów załamuje prawdę o analizowanych zjawiskach. „Second, Gouldner focused on the theorist's implicit and explicit assumptions and 'givens', and their effects on the choice of problems. In Gestalt terms ${ }^{19}$, this calls for seeing the 'ground' as being equally revealing, if not more so, than the 'figure'. Such analysis often uncovers fallacies embedded

18 J. Szacki, Historia myśli socjologicznej. Wydanie nowe, Warszawa 2002, s. 489.

19 Termin wywiedziony z psychologii postaci lub gestaltyzmu. 
in the conventional wisdom” 20 . Teorie w swojej postaci „odkrywają” nam prawdę o danych zjawiskach, gdy analizujemy je w sposób całościowy. Nie możemy podmiotu i przedmiotu badań traktować, jako odrębnych. Jak wskazuje Anna Wyka, „oba podmioty interakcji badawczej mają pewne wspólne cechy oraz uczestniczą w ramach »wspólnej« rzeczywistości. Określenie »wspólna« opatruję cudzysłowem dlatego, że nigdy nie jest to pełna identyczność sytuacji dla każdej ze stron, ale można próbować taką wspólnotę stwarzać" ${ }^{21}$. Należy więc przełamać tę szkodliwą dla socjologii linię demarkacyjną, odsłaniając tym samym bogactwo obserwowalnych prawd o świecie. Nie należy wytyczać i podtrzymywać granic czy podziałów, należy je przekraczać poprzez techniki transgresji, albowiem to, co społecznem jest niezwykle zróżnicowane. Wielowymiarowość tę należy zaobserwować w całej okazałości.

Gouldner, eksplorując problematykę socjologiczną, niejednokrotnie przyjmował ukryte założenia jako problematyczne (latent assumptions as problematic). Stąd też jego manifest The Coming Crisis of Western Sociology pozostaje przejawem współtworzenia subdyscypliny określonej przez autora mianem socjologii socjologii ${ }^{22}$ (Sociology of sociology). Postulat ten w całej okazałości ujawnił społeczną „infrastrukturę" oraz uwidocznił utajone przesłanki orientujące pracę badaczy społecznych. Mając na względzie pozycję socjologii w panteonie nauki, wskazał cztery okresy historyczne współtworzące jej treści: pozytywizm socjologiczny, marksizm, socjologię klasyczną i parsonsowski funkcjonalizm strukturalny, proponując jedocześnie socjologię refleksyjną jako pomysł na rozwiązanie „kryzysu” tradycyjnej koncepcji „czystej socjologii”23. Dokonując analizy wielu interesujących zagadnień, Gouldner świadomy był istnienia jawnych oraz ukrytych, niewidocznych czy nawet utajonych poprzez jakieś szczególne siły czy reżimy społeczne, zjawiska. Jeśli coś jest zakryte przed nami, to zakryte jest z jakiegoś konkretnego powodu. Domagał się zdemaskowania czy wręcz dokonania demistyfikacji ich ukrytych funkcji. Słusznie wyraził to stanowisko Janusz Mucha, wskazując, że „(z)adaniem teoretyków jest więc pomaganie ludziom w odnajdywaniu prawdy, a przy tym pomaganie w kształtowaniu krytycznego stosunku do wieści dobrych i umiejętności akceptowania faktów prawdziwych, choćby nawet dla nich niepomyślnych"24.

Trzeci wymiar programu intelektualnego odnosi się do kontekstu wiedzy. "Third, Gouldner showed how important it is to know and analyze the influence of

${ }^{20}$ W.R. Nord, op. cit., s. 351.

21 A. Wyka, Badacz społeczny wobec doświadczenia, Warszawa 1993, s. 49.

22 J. Mucha, Socjologia jednostek i teoria krytyczna. Konferencja lizbońska o aktualnych debatach w socjologii teoretycznej, „Studia Humanistyczne AGH” 8, 2010, s. 9.

${ }^{23}$ K. Iwińska, Być i działać w społeczeństwie. Dyskusje wokót teorii podmiotowego sprawstwa, Kraków 2015, s. 12.

${ }^{24}$ J. Mucha, Socjologia jako krytyka społeczna. Orientacja radykalna i krytyczna we współczesnej socjologii zachodniej, Warszawa 1986, s. 144. 
historical and personal contexts on knowledge. The theorists' commitments, personal tensions, and social position help to shape knowledge" ${ }^{25}$. Wnikliwa analiza założeń teoretycznych oraz towarzyszących im kontekstów społecznych, historycznych, demograficznych czy intelektualnych kształtuje wrażliwość badaczy. Twórczy proces poznania naukowego w określonej dyscyplinie wymaga od naukowca nabycia określonego rodzaju wiedzy. Wiedza ta odpowiednio zagospodarowana może przyczynić się do wypracowania rezultatów w postaci określenia ich podobieństwa, różnic czy nowych charakterystyk. Stanowisko to potwierdza również Józef Niźnik, wskazując, że „przywiązanie do przeszłości jest niemal powszechnie uznawane za właściwość socjologii, która bez wątpienia różni się od innych dyscyplin naukowych"26.

Klasyczne typologie wynikające z podejścia marksistowskiego (ideologia burżuazyjna umacniania fałszywą świadomość klasową) czy weberowskiego (modelowa „stalowa klatka” biurokracji) nie przystawały do nowych okoliczności. Postrzegając klasę społeczną jako postaci zakorzenione w zupełnie odrębnym kontekście, Gouldner wyróżnił kilka modeli orientacji zawodowych wpisujących się w konstrukt kosmopolityczno-lokalny. Model lokalny rozwarstwia się na cztery klastry - the dedicated, the true bureaucrat, the homeguard, the elders, natomiast model kosmopolitów polaryzuje się na dwie ich wariancje - outsiders, the empire builders. Proponowane modele odzwierciedlają więzi łączące pracowników z organizacjami, zakorzenione w aspiracjach pracowników, ich pozycji społecznej czy pozycji zawodowej.

Ostateczna postać wspomnianych modeli jest również wynikiem prac wielu zespołów badawczych, udoskonalających ów teoretyczny konstrukt rodzajowych praktyk kulturowych potwierdzonych w toku badań empirycznych. Ciekawsze rozwiązania tego problemu prezentujące warsztat teoretyczno-metodologiczny prezentują Berger i Grimes ${ }^{27}$, Flango i Brumbaugh ${ }^{28}$, Goldberg, Baker i Rubenstein ${ }^{29}$ czy Stahl, Manly i McNichols ${ }^{30}$. Prace poszczególnych badaczy czynione były w różnych systemach zawodowych, ujawniły jednak zbieżność uwarunkowań wpływających na mechanizmy kształtujące status wyodrębnionych modeli.

25 W.R. Nord, op. cit., s. 351.

26 J. Niźnik, Socjologia jako nauka nie podlegająca rozwojowi, [w:] Rozwój nauki a społeczny kontekst poznania, red. J. Niżnik, Warszawa 1987, s. 131.

27 P.K. Berger, A.J. Grimes, Cosmopolitan-local: A factor analysis of the construct, „Administrative Science Quarterly” 18, 1973, s. 223-235.

28 V.E. Flango, R.B. Brumbaugh, The dimensionality of the cosmopolitan-local construct, „Administrative Science Quarterly” 19, 1974, s. 198-210.

29 L.C. Goldberg, F. Baker, A.H. Rubenstein, Local-cosmopolitan: Unidimensional or multidimensional?, „American Journal of Sociology” 70, 1965, s. 704-710.

${ }^{30}$ M.J. Stahl, T.R. Manley, C.W. McNichols, Operationalizing the moskos institution-occupation model: An application of Gouldner's cosmopolitan-local research, „Armed Forces and Society” 6, 1980, s. 257-269. 
Czwarty wymiar programu intelektualnego odnosi się do umiejętności stawiania wnikliwych pytań i poszukiwania ich odpowiedzi. Mogą one przyjmować następującą postać:

1) Are its consequences liberative or repressive?

2) Do the consciences bind humans to the social world as it now exists or enable them to transcend it?

3) What are the background assumptions? That is, what are the unpopulated and unlabeled assumptions? What are the givens?

4) Closely related - what is taken as problematic and what is ignored?

5) Is the glass half full or half empty? In other words, does the theorist reflect a generally positive view of the social conditions being analyzed (the half-full portion) or a negative view (the half-empty portion)?

6) What is the sentiment relevance of a theory? That is, what emotional reactions does it evoke?

7) What are the permitted or normal social worlds and what are the unpermitted or abnormal ones? For example, a theory may represent a theorist's efforts to transform an unpermitted world such as one where power and goodness do not go together into a permitted world where they do.

8) What are the metaphors? What do they accentuate and suppress?

9) What are the personal tensions that the theorist is experiencing? ${ }^{31}$

Przedstawione pytania były niezwykle pomocne w procesie analiz naukowych. Analiza prac Gouldnera potwierdza jego schematyczność w tym zakresie. Pytania te niejako spajają poprzednie trzy punkty programu intelektualnego. Są one istotne, ponieważ skłaniają badaczy do poszukiwania głębszych odpowiedzi objaśniających społeczny kontekst.

"Finally, there was a pervasive theme that was made explicit in the title of his posthumously published book pt. Against fragmentation: The origins of Marxism and the sociology of intellectuals"32. Ten piąty wymiar programu intelektualnego odnosi się do łagodzenia skutków fragmentacji współczesnej nauki wyrażającej się w postępującej instytucjonalizacji dyscyplin. Powstawanie w obrębie dyscypliny wąskich specjalności nie zawsze może być postrzegane jako miara postępu naukowego. W jego ujęciu holistyczna wizja człowieka uległa gdzieś po drodze rozczłonkowaniu w wyniku ciągłego upraszczania i fragmentacji myśli, co nie sprzyja naukom. Złożone zjawiska można uprościć koncepcyjnie w celu ich zrozumienia, ale zubożanie ich postaci czy dokonywanie rozmaitych zmian mających na celu usankcjonowanie ich wieloznaczności nie jest wskazane. Łatwo popaść w pułapkę tego rodzaju uproszczeń prowadzących do niewiarygodnych postaci, na wskroś bezużytecznych, a nawet nieuprawnionych. Przekraczanie teorii wymaga całościowego jej zrozumienia, pełnego oraz adekwatnego, w przeciwnym razie wytwarza się jej deformacje. Gouldner głęboko podziwiał szlachetny holizm dostrzeżony w dorobku Marksa, jednak nie był ślepy na jego niedoskonałości. Podzielał radykalną aspirację marksizmu, ale nie pozwalał, aby ta sympatia przetrwała w sposobie stawiania i odkrywania najbardziej niezręcznych i trudnych

31 W.R. Nord, op. cit, s. 352-353.

${ }^{32}$ Ibidem. 
pytań, prowokujących zarówno do myślenia, jak i formułowania oryginalnych odpowiedzi ${ }^{33}$. Gouldnera często przedstawia się jako marksistowskiego banitę, a pełnił on raczej funkcję demistyfikatora Marksa ${ }^{34}$, wykrywając i ujawniając to, co nie zostało dostrzeżone.

Nawiązując do immanentnego traktowania wszystkich wymiarów naukowego poznania, Gouldner wskazuje na siłę przyczynową pewnych dominujących sił społecznych. Te siły dominacji są każdorazowo ugruntowywane poprzez swoiste reżimy. Postaci tychże reżimów zależne są od analizowanych zagadnień. Reżimy te muszą zostać właściwie zaobserwowane, poddane analizie, co nadaje stosowną wagę ich socjologicznym interpretacjom.

\section{Technologia jako dyskurs ideologii}

Niezwykle interesującym reżimem organizującym rzeczywistość społeczną jest ideologia. Alvin W. Gouldner w swojej pierwszej uznanej trylogii - The Dialectic of Ideology and Technology: The Origins, Grammar, and Future of Ideology - wskazał na ideologię jako system symboli mocniej zakorzeniony w społeczeństwie niż mit czy religia. Dokonuje on socjogenezy ideologii wyrastających od czasów średniowiecza i towarzyszących jej ruchów, takich jak feudalizm, religia, oświecenie, nauka, kapitalizm, burżuazja, socjalizm czy technologia ${ }^{35}$. Ukazuje jej tożsamość, wielość obliczy, potencjał przekształceń oraz fenomen generowanych mechanizmów zmiany społecznej, jednak nie formułuje jednoznacznej definicji tego terminu. Każdorazowo starzejąca się siłą rzeczy ideologia nie zapewnia ciągłości i stabilności struktur społecznych, dlatego jest wypierana przez reżim nowej jej postaci. Jednocześnie wszelkie ideologie, niezależnie od różnic im towarzyszących, służą propagowaniu zmian dla istniejących ruchów społecznych. Każda ideologia zostaje ostatecznie przezwyciężona przez kolejną jej formę postulowaną przez intelektualny establishment.

Każda ideologia jest zapośredniczona w społecznym kontekście i proklamowana przez określoną grupę propagatorów w sferze publicznej. Ideologia odzwierciedla systemy przekonań, refleksji, stanowisk, ideałów czy wartości cennych dla całych społeczności lub też poszczególnych grup interesu, dążących do przezwyciężenia istniejących ograniczeń. Ideologia służy również mobilizacji mas do realizacji określonych celów. Zaznacza się, że ideologia w przeciwieństwie do funkcji mitu dokonuje raczej segregacji grup społecznych, niż sprzyja ich integracji.

33 J. Grumley, Review: Against Fragmentation: The Origins of Marxism and the Sociology of the Intellectuals, „Thesis Eleven” 22, 1989, s. 130.

${ }^{34}$ A.W Gouldner, The Dialectic of Ideology..., s. 12.

${ }^{35}$ P. Kriese, Book reviews: "The Dialectic of Ideology and Technology, The Origins, Grammar and Future of Ideology”. By Alvin W. Gouldner, „Political Research Quarterly” 3, 1978, s. 293. 
Czynione jest to poprzez fenomen utajonej „rewolucji komunikacyjnej”36, niezauważonej czy wręcz dyskretnie upowszechnianej w dyskursie publicznym. Treści ideologiczne stają się pewną wizją czy orientacją upowszechnianą przez jej propagatorów. Rozróżnienia pomiędzy nauką a ideologią możemy dokonać za pomocą następujących przesłanek. Nauka opiera hipotezy na faktach, podając wszystko w wątpliwość, natomiast ideologowie zakładają, że ich założenia są faktami, przyjmują więc iluzję za pewnik ${ }^{37}$. Niezależnie od natury ideologii (społecznej, politycznej, naukowej czy innej) staje się ona swoistą użyteczną „siłą” dokonującą przekształceń struktury społecznej.

Sam termin ideologii nie jest definiowany w spójny sposób. Malcolm B. Hamilton wylicza 27 ważniejszych definicji tegoż pojęcia, wskazując, że liczba istniejących definicji jest równa niemalże liczbie teoretyków rozważających tą kwestię. Analizując wkład Gouldnera w analizę tego zagadnienia, nadał ideologii następujące znaczenie:

An ideology is a system of collectively held normative and reputedly factual ideas and beliefs and attitudes advocating a particular pattern of social relationships and arrangements, and/or aimed at justifying a particular pattern of conduct, which its proponents seek to promote, realise, pursue or maintain ${ }^{38}$.

Ideologia nie została uśmiercona $\mathrm{w}$ miarę przekształceń cywilizacyjnych, wręcz przeciwnie, ulokowała się w postaci dyskursu przyjmującego rozmaite, utajone postaci. Wśród tych postaci wymienia się na przykład: niewolnictwo, feudalizm, kapitalizm, porządek burżuazyjny, pozytywizm, komunizm czy nawet technologię. Niewątpliwie dla Gouldnera główną wadą ideologii jest jej obiektywizm oraz brak refleksyjności samej w sobie. Być może z tego powodu nie opowiadał się za żadną z nich w rodzimej nauce, przyjmując stanowisko krytycznego realizmu. Jak stwierdza Alvin W. Gouldner, formułowanie każdej ideologii jest subiektywistyczne, jej propagatorzy „odrzucają ideę, że oni i ich teorie są nosicielami sprzeczności, fałszywej świadomości oraz mistyfikacji” ${ }^{39}$. Nosicielami fałszywej świadomości mogą być również badacze społeczni, którzy w istocie są zapośredniczeni w społeczeństwie. Świadomie lub nieświadomie angażują się w stanowienie treści o nim w postaci wiedzy naukowej. Stąd też powiązanie sfery aksjologicznej z praktyką dochodzenia do prawdy, niezależnie od jej postaci - korzystnej, obojętnej czy niekorzystnej.

Odnosząc się na przykład do kwestii „nowej klasy” intelektualistów, Gouldner wskazał na ich zupełnie odmienny status. W ujęciu marksistowskim naukowiec odgrywał rolę sługi kierującego się bezstronnym rozumem, ich światopogląd

36 A.W. Gouldner, The Dialectic of Ideology..., s. 195.

37 R.P. Mohan, G.C. Kinloch, Ideology, myths, and social science, [w:] Ideology and the Social Sciences: Contributions in Sociology, red. R.P. Mohan, G.C. Kinloch, London 2000, s. 13.

${ }_{38}$ M.M. Hamilton, The Elements of the Concept of Ideology, „Political Studies” 35, 1987, s. 38.

39 A.W. Gouldner, The Dialectic of Ideology ..., s. 14. 
nie był uwikłany w żadne interesy. W jego opinii „nowa klasa” intelektualistów „pchała nie inny kurhan niż ich własny”, realizowali oni często jakieś własne cele. Nie byli już bezstronnymi obserwatorami rzeczywistości społecznej, ich zaangażowanie mogło być motywowane utajonymi interesami. Nie zgadzał się z tym stanowiskiem James J. Chriss: wierzył, że intelektualiści są wewnętrznie dobrzy i nie są zdolni do bycia złymi, sprytnymi czy żądnymi władzy. Natomiast Gouldner wyraził przeciwne stanowisko, ostrzegał: uważajcie na intelektualistów, oni są najniebezpieczniejszymi ludźmi na świecie ${ }^{40}$.

Kolejnym reżimem dokonującym przekształceń „tkanki” społecznej jest ideologiczny dyskurs technologii. Wpływ technologii na społeczeństwo jest niepodważalny, dynamizuje ona rozwój sił tkwiących w jego strukturach. Homo technologicus jest wytworem kapitalistycznego społeczeństwa przemysłowego. Technologia pozostaje istotną nadbudową ideologiczną przekształcającą stosunki społeczne. Ujawnia się ona w postaci determinizmu technologicznego, wizji wręcz nieustannego postępu niezależnego od woli człowieka. Gouldner w taki oto sposób wywodzi sprzężenie nauki i technologii: „Science took technology out of the artisan's dingy shed into the cloistered halls of the university and its laboratories [...]"41. Wykształcona klasa merytokratów czy technokratów legitymizuje swoje poczynania zarówno poprzez sprzężenie nauki i technologii, jak i poprzez biurokratyczną nadbudowę organizacji społecznej. Dyskurs technologiczny przekonuje do następujących wartości cywilizacji technologicznej: do efektywności, wydajności, użyteczności, pomijając niejednokrotnie wartości wyższe, takie jak dobro, wolność czy prawdę. Technologia sama w sobie nie jest zła, natomiast różne mogą być intencje ludzi wprowadzających ją do użytku. Technologia jest więc wyrazem instrumentalnej interwencji kartezjańskiego, racjonalnego podmiotu nad przyrodą.

\section{Wnioski}

Realizowany przez Gouldnera program intelektualny wydaje się niezwykle inspirujący. James J. Chriss, charakteryzując biogram refleksyjnych dociekań autora, dostrzega stosowanie przez niego dialektyki heglowskiej, wskazując, że sam Gouldner wydawał się uwięziony w rozwoju ducha poprzez trzy odrębne etapy: 1945-1960 - tezy; 1960-1970 - antytezy; 1970-1980 - syntezy lub formułowania nowej tezy ${ }^{42}$. Spoglądając na program intelektualny Gouldnera, tworzy on spójną całość. Może ona służyć przełamywaniu ograniczeń i otwierać możliwość formułowania twórczych uogólnień. Odczytywanie dzieł Gouldnera, zarówno po raz pierwszy, jak i po raz kolejny, odsłania nam niezwykle interesujące

40 A.W. Gouldner, The dark side of the dialectic: Toward a new objectivity, „Sociological Inquiry” 46, 1976, doi: 10.1111/j.1475-682X.1976.tb00743.x (dostęp: 12.12.2018).

41 A.W. Gouldner, The Dialectic of Ideology..., s. 251.

42 J. Chriss, Alvin W. Gouldner: Sociologist and Outlaw Marxist, London 1999. 
pryzmaty, poprzez które możemy spoglądać na otaczający nas świat społeczny. Dorobek Gouldnera tworzy swoisty „róg obfitości”, z tych dobrodziejstw naukowych możemy korzystać, próbując uchwycić interesujące nas przemiany społeczne. Wiedza ta kształtuje w nas świadomość świeżego spojrzenia na wiele interesujących kwestii. Nabywanie owej wiedzy stanowi dla nas wyraz troski o adekwatne lokowanie naszych naukowych rozważań i interpretacji oraz stanowienie naukowych uogólnień.

\section{Bibliografia}

Babbie E., Podstawy badań społecznych, przeł. Betkiewicz W. et al., Warszawa 2009.

Berger P.K., Grimes A.J., Cosmopolitan-local: A factor analysis of the construct, "Administrative Science Quarterly" 18, 1973.

Breines P., Gouldner, Marxism, and the intellectuals, „Theory and Society” 15, 1986.

Cackowski Z., Człowiek jako podmiot działania praktycznego i poznawczego, Warszawa 1979.

Chriss J., Alvin W. Gouldner: Sociologist and Outlaw Marxist, London 1999.

Czekaj K., Socjologia Szkoły Chicagowskiej i jej recepcja w Polsce, Katowice 2007.

Flango V.E., Brumbaugh R.B., The dimensionality of the cosmopolitan-local construct, „Administrative Science Quarterly" 19, 1974.

Goldberg L.C., Baker F., Rubenstein A.H., Local-cosmopolitan: Unidimensional or multidimensional?, „American Journal of Sociology” 70, 1965.

Gouldner A.W., Against Fragmentation: The Origins of Marxism and the Sociology of Intellectuals, New York 1985.

Gouldner A.W., Anti-Minotaur: The myth of a value-free sociology, „Social Problems” 9, 1962.

Gouldner A.W., Anty-Minotaur, czyli mit socjologii wolnej od wartości, [w:] Kryzys i schizma, t. 1, red. E. Mokrzycki, Warszawa 1984.

Gouldner A.W., The Coming Crisis of Western Sociology, New York 1970.

Gouldner A.W., The Dark Side of the Dialectic: The Future of Intellectuals and the Rise of the New Clas, Oxford 1982.

Gouldner A.W., The dark side of the dialectic: Toward a new objectivity, „Sociological Inquiry” 46, 1976, 10.1111/j.1475-682X.1976.tb00743.x.

Gouldner A.W., The Dialectic of Ideology and Technology The Origins, Grammar, and Future of Ideology, New York 1976.

Gouldner A.W., For Sociology: Renewal and Critique in Sociology Today, New York 1973.

Gouldner A.W., Kryzys socjologii zachodniej, przeł. P. Tomanek, Kraków 2010.

Gouldner A.W., News and social science as ideology, „Quarterly Journal of Ideology” 2. 1978.

Gouldner A.W., The norm of reciprocity; preliminary statement, „American Sociological Reviev” 25, 1960. Gouldner A.W., Norma wzajemności. Preliminaria, [w:] Współczesne teorie wymiany spoŁecznej. Zbiór tekstów, red. M.M. Kempny, J. Szmatka, Warszawa 1992.

Gouldner A.W., Organizational analysis, [w:] Sociology Today: Problems and Prospects, red. R.K. Merton, L. Broom, L.S. Cottrell Jr., New York 1959.

Gouldner A.W., Patterns of Industrial Bureaucracy, Glencoe 1954.

Gouldner A.W., Peterson R.A., Notes on Technology and the Moral Order, Indianapolis 1962.

Gouldner A.W., Reciprocity and autonomy in functional theory, [in:] Symposium on Sociological Theory, red. L. Gross, Evanston 1959.

Gouldner A.W., Some observations on systematic theory, [w:] Sociology in the United States of America, red. H. Zetterberg, Paris 1956.

Gouldner A.W., Studies in Leadership, New York 1950. 
Gouldner A.W., The Future of Intellectuals and the Rise of the New Class, New York 1979.

Gouldner A.W., The Two Marxisms, New York 1980.

Grumley J., Review: Against fragmentation: The origins of marxism and the sociology of the intellectuals, „Thesis Eleven” 22, 1989.

Hamilton M.M., The elements of the concept of ideology, „Political Studies” 35, 1987.

Horkheimer M., Zmierzch. Notatki z Niemiec 1931-1934, przeł. H. Walentowicz, Warszawa 2002.

Iwińska K., Być i działać w społeczeństwie. Dyskusje wokół teorii podmiotowego sprawstwa, Kraków 2015.

Kriese P., Book reviews: "The Dialectic of Ideology and Technology, The Origins, Grammar and Future of Ideology”. By Alvin W. Gouldner, „Political Research Quarterly” 3, 1978.

Mohan R.P., Kinloch G.C., Ideology, myths, and social science, [w:] Ideology and the Social Sciences: Contributions in Sociology, red. R.P. Mohan, G.C. Kinloch, London 2000.

Morrow R., The dialectic of ideology and technology: The origins, grammar and future of ideology, „Telos” 32, 1977.

Mucha J., Socjologia jako krytyka społeczna. Orientacja radykalna i krytyczna we wspótczesnej socjologii zachodniej, Warszawa 1986.

Mucha J., Socjologia jednostek i teoria krytyczna. Konferencja lizbońska o aktualnych debatach $w$ socjologii teoretycznej, „Studia Humanistyczne AGH” 8, 2010.

Niesporek A., Alvin Gouldner - teoretyk czy socjologiczny banita?, [w:] A.W. Gouldner, Kryzys socjologii zachodniej, przeł. P. Tomanek, Kraków 2010.

Niźnik J., Socjologia jako nauka nie podlegająca rozwojowi, [w:] Rozwój nauki a społeczny kontekst poznania, red. J. Niżnik, Warszawa 1987.

Niźnik J., Socjologia wiedzy. Zarys historii i problematyki, Warszawa 1989.

Nord W.R., Alvin W. Gouldner as Intellectual Hero, „Journal of Management Inquiry” 1, 1992.

Stahl M.J., Manley T.R., McNichols C.W., Operationalizing the moskos institution-occupation model: An application of Gouldner's cosmopolitan-local research, „Armed Forces and Society” 6, 1980.

Szacki J., Historia myśli socjologicznej. Wydanie nowe, Warszawa 2002.

Wyka A., Badacz społeczny wobec doświadczenia, Warszawa 1993.

\section{The phenomenon of the "horn of abundance" in the factual reconstruction of the intellectual program of Alvin Ward Gouldner}

\section{Summary}

By making a quick systematization of the sociological achievements in the field of scientific cognition and technological progress, we are facing a real challenge. The phenomenon of the "horn of abundance" in the factual reconstruction of sociological explanatory visions explaining scientific cognition and technological progress almost overwhelms the multiplicity of the proposed concepts. Many of the proposed polarized approaches are maintained in terms of convergence, while others remain divergent. Systematization of even selected theoretical positions goes far beyond the scope of this study, hence my attention is focused on the character of Alvin Ward Gouldner. The subject of my research activities is the reconstruction of the intellectual program expressed in the most important works of this sociologist. He is such an interesting figure of the intellectual establishment that many of his works can be considered a "magnum opus" of sociology. The "map" of relational themes, threads and issues co-creates extremely detailed and multidimensional achievements. Undoubtedly, Gouldner's remarkable sense of intellectual awareness resounds today in his works and inspires social scientists. One can only regret the lack of sufficient dissemination of Gouldner's intellectual ideas in our native sociology. While appreciating the value of such theoretical-empirical efforts, this article tries to minimize this gap by presenting Gouldner's achievements that have not yet been translated into Polish. 